\title{
Temporal changes in rat Leydig cell function after the induction of bilateral cryptorchidism
}

\author{
G. P. Risbridger, J. B. Kerr, R. Peake, K. A. Rich and D. M. de Kretser \\ Department of Anatomy, Monash University, Clayton, Victoria 3168, Australia
}

\begin{abstract}
Summary. Adult rats were made bilaterally cryptorchid and studied at intervals of 3, 7,14 or 21 days to study temporal changes in Leydig cell function. Serum FSH and LH levels were measured and the cross-sectional area of the Leydig cells assessed by morphometry. The function of the Leydig cells was judged by the binding of ${ }^{125}$ I-labelled hCG to testicular tissue in vitro and the testosterone response of the testis to hCG stimulation in vitro. By 3 days after cryptorchidism, the binding of labelled hCG to testicular tissue was significantly decreased compared to that of controls, but the testes were able to respond to hCG stimulation in vitro. At 7, 14 and 21 days after cryptorchidism, an enhanced testosterone response was observed and the size of the Leydig cells was significantly greater than that of the controls, which indicated increased secretory activity by the cryptorchid testis. Although serum FSH levels were significantly elevated after 3 days of cryptorchidism, serum LH levels did not rise until 7 days, thereby suggesting that the loss of receptors is unlikely to result from down-regulation by LH. The reduced testosterone response of the cryptorchid testis in vivo to low doses of $\mathrm{hCG}$ and the enhanced response at high doses are probably related to the reduced blood flow to the cryptorchid testis and the decreased sensitivity of the Leydig cells induced by LH/hCG receptor loss.
\end{abstract}

\section{Introduction}

Surgically induced cryptorchidism results in a progressive degeneration of the germ cells of the testis (Clegg, 1963). Bilateral cryptorchidism also results in some degree of Leydig cell failure (Kerr, Rich \& de Kretser, 1979b); 1 month after the induction of cryptorchidism, serum LH levels were elevated, serum testosterone levels were significantly lower or unchanged, and a diminished testosterone response to hCG stimulation was observed in vivo compared to control animals. However, the Leydig cells were hypertrophied and their cytological features were suggestive of increased steroid secretion consistent with the enhanced secretory activity observed in response to maximal hCG stimulation in vitro (de Kretser, Sharpe \& Swanston, 1979). A marked reduction in the ability of the cryptorchid testis to bind labelled hCG in vitro was associated with the changes in Leydig cell function (de Kretser et al., 1979). It was consequently postulated that the increased LH secretion may have secondarily affected Leydig cell function, causing hypertrophy and down-regulating the number of $\mathrm{LH} / \mathrm{hCG}$ receptors which, in turn, may have altered the sensitivity of the testis to hCG stimulation in vivo.

In this study we have examined Leydig cell function after the induction of bilateral cryptorchidism to establish the temporal relationship between the elevation of serum gonadotrophin levels and the changes in the steroidogenic secretory capacity and hCG binding in vitro. Morphometric analyses were also performed to assess the increase in Leydig cell size. 


\section{Materials and Methods}

\section{Animals}

Mature Sprague-Dawley rats aged 2-3 months were made surgically cryptorchid by relocation of the testis into an abdominal position and closure of the inguinal canal. Animals were killed by decapitation $3,7,14$ or 21 days after the induction of bilateral cryptorchidism and trunk blood was collected and stored at $-20^{\circ} \mathrm{C}$ until assayed for $\mathrm{LH}, \mathrm{FSH}$ and testosterone. Control animals were sham-operated by opening the scrotum and gently displacing the testes into the abdomen without closure of the inguinal canal.

\section{Measurement of in-vitro binding of ${ }^{125}$ I-labelled $h C G$}

The testes were excised, weighed, decapsulated and placed in ice-cold phosphate-buffered saline (PBS), pH 7.2. The testes were homogenized by hand using a glass-teflon homogenizer and were centrifuged at $20000 \mathrm{~g}$ for $15 \mathrm{~min}$. The pellet was resuspended, centrifuged again and stored in $1 \mathrm{ml} \mathrm{PBS} / 0.1 \% \mathrm{BSA}$ at $-20^{\circ} \mathrm{C}$ before use. After thawing, the pellets were dispersed at a concentration of $200 \mathrm{mg} / \mathrm{ml}$ in PBS. Highly purified hCG (CR 121 : activity 9286 i.u. $/ \mathrm{mg}$, kindly provided by the National Pituitary Agency, NIH, Bethesda, Maryland, U.S.A.) was iodinated with chloramine $\mathrm{T}$ to a specific activity of $30-50 \mu \mathrm{Ci} / \mu \mathrm{g}$ by the method of Greenwood, Hunter \& Glover (1963). Triplicate $100-\mu \mathrm{l}$ aliquots of the suspension were incubated with $100 \mu \mathrm{l}$ ${ }^{125}$ I-labelled hCG (100000 c.p.m.) and $50 \mu \mathrm{l}$ PBS buffer for $16 \mathrm{~h}$ at $22^{\circ} \mathrm{C}$. The non-specific binding of ${ }^{125}$ I-labelled hCG was determined by the addition of an excess of hCG (100 i.u. in 50 $\mu l$ PBS; Pregnyl: Organon) instead of buffer alone. The incubation was terminated by the addition of $3 \mathrm{ml} 0.9 \%(\mathrm{w} / \mathrm{v}) \mathrm{NaCl}$, the tubes were centrifuged at $1500 \mathrm{~g}$ for $30 \mathrm{~min}$ and the resulting radioactivity in the pellet was measured in a Packard gamma spectrometer. The lower speed of centrifugation resulted in only an $0.5-1.0 \%$ decrease in ${ }^{125}$ I-labelled hCG bound to tissue when compared to centrifugation at $20000 \mathrm{~g}$; consequently the lower speed was used routinely because of increased capacity of the centrifuge. The $\mathrm{LH} / \mathrm{hCG}$ binding was expressed as ng hormone bound per testis.

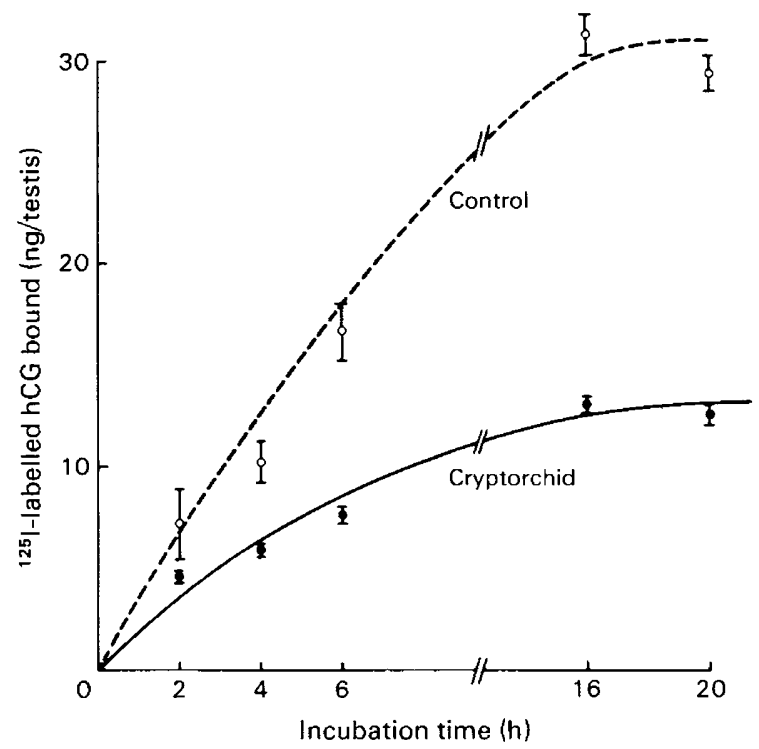

Text-fig. 1. The effect of time on the binding of ${ }^{125}$ I-labelled hCG to testicular homogenates from normal and cryptorchid rat testes. Each point represents the mean \pm s.e.m. of 5 replicates. 
The possibility that the presence of degenerating germ cells in the homogenates of testes from cryptorchid rats may alter the kinetics of ${ }^{125} \mathrm{I}$-labelled hCG, in comparison to preparations from control rats, was evaluated by performing a time-course of binding at $22^{\circ} \mathrm{C}$ for $16 \mathrm{~h}$ for both preparations. Although the total binding to homogenates from cryptorchid testes were lower, the kinetics did not differ from those for control testicular homogenates (Text-fig. 1).

\section{Stimulation of testosterone production by $h C G$ in vitro}

The testes were removed, weighed, decapsulated and placed in $2 \mathrm{ml}$ Krebs-Ringerbicarbonate buffer (Dawson, Elliot, Elliot \& Jones, 1969) containing $1 \mathrm{mg}$ glucose/ml (KRBG). Testosterone production in response to hCG was determined by methods previously published (de Kretser et al., 1979). At 2 weeks after the induction of cryptorchidism, the in-vitro testosterone response to different doses of hCG (2-1500 mi.u./ml: (Pregnyl: Organon) was determined. Unless indicated the concentration of hCG used in the studies was $700 \mathrm{mi.u} . / \mathrm{ml}$.

\section{Studies on Leydig cells isolated from cryptorchid rats}

Preliminary attempts to isolate Leydig cells from rats 21 or 28 days after inducing cryptorchidism by the method of Mendelson, Dufau \& Catt (1975) met with considerable difficulty. This presumably resulted from increased collagen accumulation in the peritubular tissue of cryptorchid rats (Kerr et al., 1979a) requiring more extensive incubation with collagenase. These extensive incubations (30-60 min) resulted in poor Leydig cell viability, especially from normal rats. However, since the present study demonstrates changes in Leydig cell function within 7 days of inducing cryptorchidism, i.e. before collagen accumulation is increased, Leydig cells were obtained by incubation with collagenase (Sigma Type 1), 0.25 $\mathrm{mg} / \mathrm{ml}$, for $15 \mathrm{~min}$ from control and cryptorchid testes. The binding of ${ }^{125} \mathrm{I}$-labelled $\mathrm{hCG}$ and the in-vitro response to $700 \mathrm{mi}$.u. hCG were then assessed.

\section{In-vivo dose-response to $h C G$}

In view of previous results (Kerr et al., 1979b), which demonstrated poor response of the cryptorchid testis to hCG stimulation in vivo but hyper-responsivity to hCG in vitro, a dose-response test to hCG stimulation in vivo was performed. Normal rats and 21day-cryptorchid rats were injected s.c. with 5,50 or 200 i.u. hCG and killed by decapitation 60 min later. This time was chosen because earlier studies in normal rats and those with spermatogenic damage from other causes showed this to be the time to achieve the maximal initial response (Rich, Kerr \& de Kretser, 1979). Similar data are available for cryptorchid rats (unpublished). The sera were separated and stored at $-20^{\circ} \mathrm{C}$ until assayed for testosterone.

\section{Radioimmunoassay of serum LH, FSH and testosterone}

FSH and LH were measured by double-antibody radioimmunoassays using methods previously described (Lee, de Kretser, Hudson \& Wang, 1975). The FSH assay utilized an antiserum raised to purified human FSH and showed less than $0.5 \%$ cross-reactivity with rat LH and TSH. Purified rat FSH (NIAMDD-FSH-I3) was iodinated with lactoperoxidase and used as tracer and NIAMDD-FSH-RP1 as standard. The antiserum (NIAMDD-LH-S4) was used to measure rat LH and purified rat LH (NIAMDD-LH-I4) was used as both tracer and standard. The intra-assay variation ranged from 7 to $9 \%$ for both assays. All samples from the study were measured in the same assay.

Testosterone was measured by a specific radioimmunoassay similar to that described by Corker \& Davidson (1978). Incubation media were assayed directly for testosterone content 
because ether-extracted and unextracted samples gave similar results. The anti-serum to testosterone was raised in sheep against testosterone-3-carboxymethyloxime coupled to bovine serum albumin and showed a $98 \%$ cross-reactivity with $5 \alpha$-dihydrotestosterone. The intra-assay coefficient of variation was $6.8 \%$ and the inter-assay coefficient of variation was $16 \%$.

\section{Histology}

The testes of rats that had been cryptorchid for $3,7,14$ or 21 days were fixed by perfusion of a mixture of glutaraldehyde ( $5 \%$ by vol.), formaldehyde ( $4 \%$ by vol.) and 2,4,6-trinitro-cresol $(0.05 \%$ by vol.) buffered to $\mathrm{pH} 7.4$ with $0.2 \mathrm{M}$-sodium cacodylate as previously described (Kerr $\&$ de Kretser, 1975). Following post-fixation in osmium tetroxide, the small pieces of testicular tissue were dehydrated and embedded in a mixture of Epon: Araldite $(1: 1, \mathrm{v} / \mathrm{v})$. Sections $0 \cdot 5-1$ $\mu \mathrm{m}$ in thickness were stained with toluidine blue and examined with a Leitz Orthoplan microscope. The cross-sectional area of Leydig cells, selected at random, was measured using a Leitz Image Analyser. Equal numbers of Leydig cells $(n=300)$ were measured from 3 animals in each of the 4 groups.

\section{Statistical analysis}

The results were subjected to analysis by Student's $t$ test except for the data in Table 1 concerning serum FSH and the incremental rise of testosterone to hCG stimulation. Due to the variance in the latter increasing with the magnitude of the mean, the data were log-transformed and subjected to analysis of variance.

\section{Results}

There was a marked reduction in testis weight after the induction of cryptorchidism (Table 1), such that at 21 days the cryptorchid testis was approximately one quarter of the weight of the control testis. There was no further decline in testis weight at 21 days after cryptorchidism.

Table 1. The effect of cryptorchidism of rats on testicular weight, serum FSH and LH concentrations, binding of ${ }^{125} \mathrm{I}$-labelled $\mathrm{hCG}$ and incremental rise of testosterone production

\begin{tabular}{|c|c|c|c|c|}
\hline & \multicolumn{4}{|c|}{ Days after induction of cryptorchidism } \\
\hline & 3 & 7 & 14 & 21 \\
\hline \multicolumn{5}{|l|}{ Testis wt (g) } \\
\hline Control & $1.53 \pm 0.06$ & $1 \cdot 15 \pm 0.06$ & $1.44 \pm 0.06$ & $1.63 \pm 0.04$ \\
\hline Cryptorchid & $1.54 \pm 0.06$ & $1.06 \pm 0.11^{*}$ & $0.47 \pm 0.04^{*}$ & $0.42 \pm 0.03^{*}$ \\
\hline \multicolumn{5}{|c|}{ Serum LH (ng/ml) } \\
\hline Control & $1.02 \pm 0.11$ & $0.69 \pm 0.11$ & $0.47 \pm 0.08$ & $0.76 \pm 0.09$ \\
\hline Cryptorchid & $0.82 \pm 0.11$ & $1.47 \pm 0.22^{*}$ & $1.72 \pm 0.14^{*}$ & $1.50 \pm 0.09^{*}$ \\
\hline \multicolumn{5}{|c|}{ Serum FSH $(\mathrm{ng} / \mathrm{ml})$} \\
\hline Control & $492 \pm 27$ & $421 \pm 18$ & $402 \pm 21$ & $544 \pm 22$ \\
\hline Cryptorchid & $767 \pm 32^{*}$ & $638 \pm 53^{* *}$ & $855 \pm 50^{* *}$ & $1093 \pm 126^{* *}$ \\
\hline \multicolumn{5}{|c|}{ Binding of ${ }^{125}$ I-labelled hCG (ng/testis) } \\
\hline Control & $16 \cdot 9 \pm 1 \cdot 3$ & $13 \cdot 3 \pm 0.5$ & $12 \cdot 7 \pm 0.5$ & $10 \cdot 3 \pm 2 \cdot 8$ \\
\hline Cryptorchid & $11 \cdot 9 \pm 1 \cdot 1^{* *}$ & $4.3 \pm 0.5^{* *}$ & $3.4 \pm 0.4^{* *}$ & $2 \cdot 0 \pm 0 \cdot 2^{* *}$ \\
\hline \multicolumn{5}{|c|}{ Incremental rise in testosterone to hCG (ng/testis) } \\
\hline Control & $350 \pm 70$ & $530 \pm 70$ & $520 \pm 80$ & $190 \pm 60$ \\
\hline Cryptorchid & $260 \pm 60^{* *}$ & $1100 \pm 140^{* *}$ & $1680 \pm 260^{* *}$ & $1560 \pm 320^{* *}$ \\
\hline
\end{tabular}

Values are mean \pm s.e.m. for 8 rats/group.

${ }^{*} P<0.05,{ }^{* *} P<0.005$ compared to controls. 
Serum FSH levels were significantly increased within 3 days and continued to rise above control values with increasing time after the induction of cryptorchidism (Table 1). Serum LH levels show considerable variability in control animals, presumably related to episodic secretion, but a significant $(P<0.05)$ rise in serum $\mathrm{LH}$ above basal levels was not apparent until 7 days after cryptorchidism; values then remained elevated throughout the study (Table 1).

The binding of labelled hCG to testicular tissue from 3-day-cryptorchid rats was significantly $(P<0.01)$ lower than that for controls. Thereafter the binding capacity of the cryptorchid testis showed a further decline, reaching $19 \%$ of control values at 21 days of cryptorchidism (Table 1). Scatchard analyses of the results after cryptorchidism for 7 days show that the loss of binding was not associated with a change in the affinity of the hormone for the receptor (Text-fig. 2). No significant difference of the slopes was found either by calculating the errors and using Student's $t$ test or by the use of a bioassay programme to test parallelism of the regression lines (Finney, 1964).

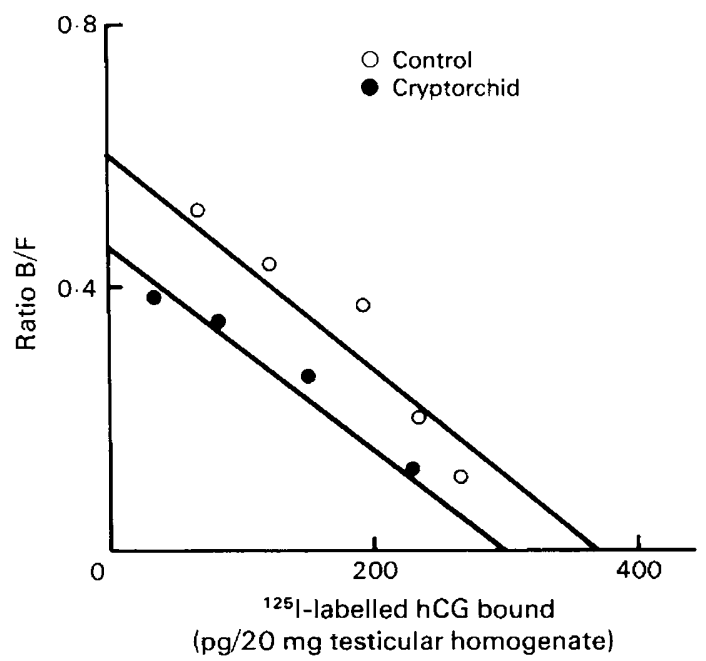

Text-fig. 2. Scatchard analysis of the binding data obtained using testicular tissue from control and 7-day-cryptorchid animals. Each point represents the mean of triplicate determinations from pooled samples of testicular tissue from the 5 animals in each group.

By 3 days after the induction of cryptorchidism, the testes were able to respond to hCG in vitro by a rise in testosterone production. There was no difference in testosterone production by control and cryptorchid testes at 3 days, but testes from 7-, 14- and 21-day-cryptorchid animals showed a significantly $(P<0.01)$ enhanced response to hCG stimulation in vitro compared to control testis (Table 1). The results in Text-fig. 3 demonstrated that at all doses of hCG the capacity of the testis to produce testosterone in vitro was greater for the cryptorchid testes. Calculation of the dose required to stimulate a half-maximal increase was $23.5 \mathrm{i} . \mathrm{u} . / \mathrm{ml}$ for the cryptorchid testis and $4.5 \mathrm{i} . \mathrm{u} . / \mathrm{ml}$ for control groups.

The size of the Leydig cells was significantly $(P<0.05)$ enlarged within 3 days of the induction of cryptorchidism and the increase was maintained (Table 2).

\section{Response of isolated Leydig cells}

Leydig cells isolated from testes 7 days after the induction of cryptorchidism demonstrated a significantly greater response of testosterone to hCG stimulation than did cells from control rats (Table 3). The binding of ${ }^{125} \mathrm{I}$-labelled hCG to Leydig cells from cryptorchid rats was reduced to $45 \%$ of that for Leydig cells from control rats (Table 3 ). 


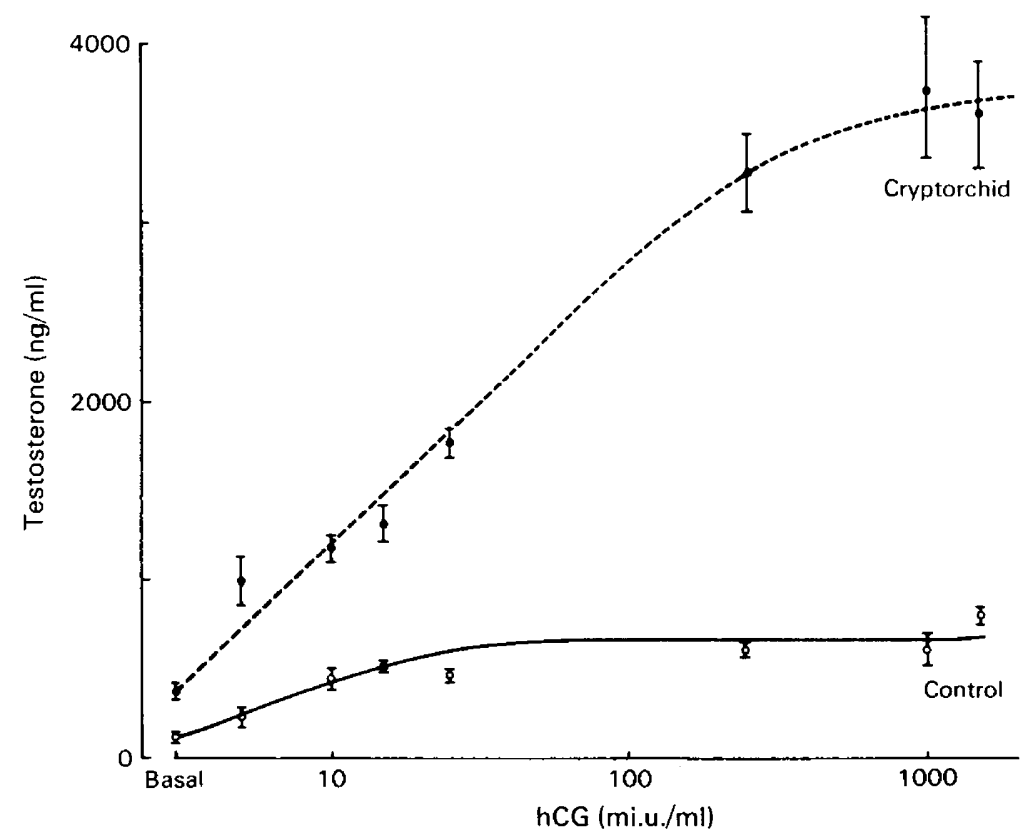

Text-fig. 3. The effect of increasing concentrations of hCG on testosterone production in vitro. Values are mean \pm s.e.m. (per $\mathrm{ml}$ of incubation buffer) for 5 testes.

Table 2. The effect of cryptorchidism in rats on the cross-sectional area of the Leydig cells

\begin{tabular}{ccc}
\hline \multirow{2}{*}{$\begin{array}{c}\text { Days after } \\
\text { cryptorchidism }\end{array}$} & \multicolumn{2}{c}{ Total cross-sectional area $\left(\mu \mathrm{m}^{2}\right)$} \\
\cline { 2 - 3 } & Control & Cryptorchid \\
\hline 3 & $108 \pm 6$ & $159 \pm 9^{*}$ \\
7 & $109 \pm 6$ & $156 \pm 6^{*}$ \\
14 & $111 \pm 5$ & $154 \pm 9^{*}$ \\
21 & $103 \pm 4$ & $166 \pm 4^{*}$ \\
\hline
\end{tabular}

Values are mean \pm s.e.m. for 300 cells in each of 3 rats/group. 0.01 .

* Significantly different from control value: $P<$

Table 3. The in-vitro responses of Leydig cells isolated from the testes of rats cryptorchid for 7 days

\begin{tabular}{|c|c|c|c|}
\hline & $\begin{array}{l}\text { No. of } \\
\text { test-tubes }\end{array}$ & Control & Cryptorchid \\
\hline \multicolumn{4}{|l|}{$\begin{array}{l}\text { Testosterone production } \\
\left(\mathrm{ng} / 10^{6} \mathrm{cells}\right)\end{array}$} \\
\hline Basal & 5 & $3 \cdot 5 \pm 0.1$ & $3 \cdot 3 \pm 0 \cdot 3$ \\
\hline hCG-stimulated & 5 & $4.5 \pm 0.1$ & $6.2 \pm 0.2^{*}$ \\
\hline $\begin{array}{l}{ }^{125} \text { I-labelled hCG binding } \\
\left(\mathrm{pg} / 10^{6} \text { cells) }\right.\end{array}$ & 3 & $48 \cdot 1 \pm 1$ & $21.8 \pm 0.9^{*}$ \\
\hline
\end{tabular}

Values are mean \pm s.e.m.; each test-tube contained $10^{6}$ cells from a different animal.

* Significantly different from control value, $P<0.001$. 


\section{In-vivo dose-response of testosterone to hCG stimulation}

Basal serum testosterone levels in controls and 21-day-cryptorchid rats did not differ (Table 4). At a dose of 5 i.u. hCG serum testosterone levels were significantly greater in control animals than in cryptorchid rats, but the reverse was true with 200 i.u. hCG. There was no difference with 50 i.u. hCG.

Table 4. The dose-response relationship between the levels of serum testosterone and the dose of hCG administered to control and 21-day-cryptorchid rats

\begin{tabular}{ccc}
\hline \multirow{2}{*}{$\begin{array}{c}\text { Dose of hCG } \\
\text { (i.u.) }\end{array}$} & \multicolumn{2}{c}{ Serum testosterone $(\mathrm{ng} / \mathrm{ml})$} \\
\cline { 2 - 3 } & Control & Cryptorchid \\
\hline 0 & $2 \cdot 0 \pm 0.2$ & $1.9 \pm 0.2$ \\
5 & $16.4 \pm 0.9$ & $8.0 \pm 1 \cdot 2^{* *}$ \\
50 & $18.3 \pm 2.2$ & $21.9 \pm 2 \cdot 5$ \\
200 & $17.6 \pm 1.5$ & $27.5 \pm 3.8^{*}$ \\
\hline
\end{tabular}

Values are mean \pm s.e.m. for 5 rats/group.

Significantly different from control values, ${ }^{*} P<$ $0.05,{ }^{* *} P<0.001$.

\section{Discussion}

This study demonstrates that the reduction in the number of available testicular $\mathrm{LH} / \mathrm{hCG}$ receptors in the cryptorchid rat is not directly related to an immediate change in peripheral $\mathrm{LH}$ concentrations. Serum LH values were unchanged 3 days after the induction of bilateral cryptorchidism and were not significantly elevated until 7 days of cryptorchidism. However, an initial significant reduction in the binding of labelled hCG to cryptorchid testis in vitro was first observed at 3 days and continued to decline to lower levels after 21 days of cryptorchidism compared to controls. The decline in hCG binding was also found in Leydig cells isolated from cryptorchid testes and incubated with the tracer in the absence of seminiferous tubules and degenerating germ cells. These results, and the demonstration that the kinetics of the binding reaction were similar in both control and cryptorchid testicular homogenates (Text-fig. 1), exclude the possibility that the loss of binding was due to damage of the iodinated hCG by lysosomal products released from degenerating germ cells.

This temporal pattern is not consistent with the explanation that the decreased binding is the result of the increased serum $\mathrm{LH}$ levels after cryptorchidism. Scatchard analysis demonstrates that the change in hCG binding is due to a loss of receptors rather than any change in the affinity of the hormone-receptor interaction. Further studies are necessary to determine the mechanism by which hCG binding is decreased following cryptorchidism.

Despite the loss of $\mathrm{LH} / \mathrm{hCG}$ receptors, the cryptorchid testis is able to respond in an exaggerated manner to hCG stimulation in vitro and does not demonstrate the desensitizing effect found after the loss of hCG receptors induced by high doses of hCG (Tsuruhara, Dufau, Cigorraga \& Catt, 1977). This provides further evidence that the loss of receptors following hCG is not the cause of the desensitization, in keeping with the data of Haour \& Saez (1978) who showed that cycloheximide could prevent the loss of $\mathrm{LH}$ receptors caused by large doses of hCG but did not prevent the desensitization process. The hypertrophy of the Leydig cells precedes the enhanced production of testosterone by the cryptorchid testis and correlates with previous ultrastructural observations of an increase in the organelles involved in steroid biosynthesis (Kerr et al., 1979b). The finding that preparations of Leydig cells isolated from 
cryptorchid testes show an exaggerated hCG-induced testosterone response is evidence that this phenomenon is not the result of any change in the steroid metabolism of damaged seminiferous tubules. The dose of hCG required to cause half-maximal stimulation of the cryptorchid testis is greater than that required by the control testis and may be a measure of decreased sensitivity consistent with the loss of LH/hCG receptors. Examination of the dose-response relationship of testosterone to hCG stimulation in vitro provided results different from those previously obtained (de Kretser et al., 1979) in that the present data show hyper-responsiveness of the cryptorchid testis at low doses of hCG. It is possible that the use of hemi-testes in the previous study may be the result of these differences as Dufau, Catt \& Tsuruhara (1971) have shown that mechanical disruption of the testis can result in decreased testosterone production. The results described herein are reproducible and are identical to those obtained using testes from rats irradiated as fetuses to cause testicular damage (Rich \& de Kretser, 1979).

Our previous studies (Kerr et al., 1979b; de Kretser et al., 1979) have demonstrated a paradox between the in-vivo hypo-responsiveness of the Leydig cell to hCG stimulation and the hyper-responsiveness in vitro, a difference attributed to the reduced blood flow to the cryptorchid testis (Damber, Bergh \& Janson, 1978) and supported by the fact that at low doses the control rats demonstrated a greater response to hCG in vivo than did the cryptorchid rats. However, at high doses of hCG the cryptorchid rats showed a greater testosterone production than controls and it is possible that the large doses of hCG have compensated for the reduced blood flow to the cryptorchid testis and overcome the decreased sensitivity resulting from the loss of $\mathrm{LH} / \mathrm{hCG}$ receptors, both of which contribute to the hyporesponsiveness of the cryptorchid testis at lower doses of hCG.

The enhanced in-vitro production of testosterone in response to hCG by cryptorchid testes is difficult to reconcile with a decreased activity of the cholesterol side-chain cleavage enzyme and $3 \beta$-hydroxysteroid dehydrogenase, and diminished androgen production as demonstrated by the conversion of precursor steroids (Inano \& Tamaoki, 1968; Le Vier \& Spaziani, 1968; Wisner \& Gomes, 1978). However, we have demonstrated a significant stimulation of pregnenolone, androstenedione and oestradiol production by cryptorchid testes during in-vitro stimulation (de Kretser et al., 1979). It is possible that the in-vitro studies using precursor conversion techniques do not accurately reflect the capacity for steroid production from endogenous unlabelled precursors. Furthermore, the hypertrophy of the Leydig cells and the increase in the organelles involved in steroid biosynthesis (Kerr et al., 1979b) support the observations in this study of increased steroidogenic capacity of these cells.

Other models of spermatogenic damage (i.e. rats treated by fetal irradiation, prolonged administration of hydroxyurea or chronic feeding of a vitamin A deficient diet) also result in elevated LH levels, hyporesponsiveness to hCG in vivo, Leydig cell hypertrophy and hyperresponsiveness to hCG in vitro and loss of LH receptors (Rich, Kerr \& de Kretser, 1979; Rich \& de Kretser, 1979). It is therefore unlikely that the changes in Leydig cell function are due solely to increased intra-abdominal temperature, and a control mechanism operating between the tubule and intertubular compartments of the testis could be involved.

Aoki \& Fawcett (1978) proposed a local control mechanism to explain the hypertrophic appearance of Leydig cells which surrounded localized areas of tubule damage induced by anti-fertility agents. They suggested that the damaged portions of the seminferous tubules might elaborate a product which results in the stimulation of Leydig cells, or that the Leydig cells might be released from the inhibitory effects of an agent secreted during normal testicular function. It is well established that cryptorchidsim causes a severe disruption of spermatogenesis (Nelson, 1951) and also alters the structure and function of the Sertoli cells as demonstrated by decreased androgen-binding protein production (Kerr et al., 1979a). Either component could be involved in the postulated control mechanism. Our present results show that the hypertrophy and hyperresponsiveness of the Leydig cells precede the rise in serum $\mathrm{LH}$, and it is therefore likely that other factors such as local mechanisms may be involved. 


\section{References}

Aoki, A. \& Fawcett, D.W. (1978) Is there a local feedback from the seminiferous tubules affecting activity of the Leydig cells? Biol. Reprod. 19, 144158.

Clegg, E. J. (1963) Studies on artificial cryptorchidism: degenerative and regenerative changes in the germinal epithelium of the rat testis. $J$. Endocr. 27, 241-251.

Corker, C.S. \& Davidson, D.W. (1978) The radioimmunoassay of testosterone in various biological fluids without chromatography. J. Steroid Biochem. 9, 373-374.

Damber, J.E., Bergh, A. \& Janson, P.O. (1978) Testicular blood flow and testosterone concentrations in the spermatic venous blood in rats with experimental cryptorchidism. Acta endocr., Copenh. 88, 611-618.

Dawson, R.M.C., Elliot, D.C., Elliot, W.H. \& Jones, K.M. (Eds) (1969) Data for Biochemical Research, 2nd edn, p. 507. Oxford University Press, London.

de Kretser, D.M., Sharpe, R.M. \& Swanston, A. (1979) Alterations in steroidogenesis and $\mathrm{hCG}$ binding in the cryptorchid rat testis. Endocrinology 105, 135138.

Dufau, M.L., Catt, K.J. \& Tsuruhara, T. (1971) Gonadotrophin stimulation of testosterone production by the rat testis in vitro. Biochim. Biophys. Acta 252, 574-579.

Finney, D. (1964) Statistical Method in Biological Assay. Charles Griffin \& Co., London.

Greenwood, F.C., Hunter, W.M. \& Glover, J.S. (1963) The preparation of ${ }^{131}$ I-labelled growth hormone of high specific radioactivity. Biochem. J. 89, 114-123.

Haour, F. \& Saez, J.M. (1978) Leydig cell responsiveness to $\mathrm{LH}-\mathrm{hCG}$ stimulation: mechanisms of hCG and steroid induced refractoriness. In Structure and Function of the Gonadotropins, pp. 497-516. Ed. K. W. McKerns. Plenum Press, New York.

Inano, H. \& Tamaoki, B.-I. (1968) Effect of experimental bilateral cryptorchidism on testicular enzymes related to androgen function. Endocrinology 83, 1074-1082.

Kerr, J.B. \& de Kretser, D.M. (1975) Cyclic variations in Sertoli cell lipid content throughout the spermatogenic cycle in the rat. J. Reprod. Fert. 43, 1-8.
Kerr, J.B., Rich, K.A. \& de Kretser, D.M. (1979a) The effects of experimental cryptorchidism on the ultrastructure and function of the Sertoli cell and peritubular tissue of rat testis. Biol. Reprod. 21, $823-838$.

Kerr, J.B., Rich, K.A. \& de Kretser, D.M. (1979b) Alterations of the fine structure and androgen secretion of the interstitial cells in the experimentally cryptorchid rat testis. Biol. Reprod. 20, 409-422.

Lee, V.W.K., de Kretser, D.M., Hudson, B. \& Wang, C. (1975) Variations in serum FSH, LH and testosterone levels in male rats from birth to sexual maturity. J. Reprod. Fert. 42, 121-126.

Le Vier, R.P. \& Spaziani, E. (1968) The influence of temperature on steroidogenesis in the rat testis. $J$. exp. Zool. 169, 113-120.

Mendelson, C., Dufau, M.L. \& Catt, K.J. (1975) Dependence of gonadotropin-induced steroidogenesis upon RNA and protein synthesis in the interstitial cell of the rat testis. Biochem. Biophys. Acta 411, 222-226.

Nelson, W.o. (1951) Mammalian spermatogenesis: effect of experimental cryptorchidism in the rat and non-descended testis in man. Recent Prog. Horm. Res. 6, 29-62.

Rich, K.A. \& de Kretser, D.M. (1979) Effect of fetal irradiation on testicular receptors and testosterone response to gonadotrophin stimulation. Int. J. Androl. 2, 343-352.

Rich, K.A., Kerr, J.B. \& de Kretser, D.M. (1979) Evidence for Leydig cell dysfunction in rats with seminiferous tubule damage. Molec. cell. Endocr. 13, $123-135$

Tsuruhara, T., Dufau, M.L., Cigorraga, S. \& Catt, K.J. (1977) Hormonal regulation of testicular luteinizing hormone receptors. Effects on cyclic AMP and testosterone responses in isolated Leydig cells. J. biol. Chem. 252, 9002-9009.

Wisner, J.R. \& Gomes, W.R. (1978) Influence of experimental cryptorchidism on cholesterol sidechain cleavage enzymes and $\Delta^{5}-3 \beta$ hydroxysteroid dehydrogenase activity in rat testes. Steroids $\mathbf{3 1}$, 189-203.

Received 15 January 1981 